Original Research Paper

\title{
Genotypic Characterization of Antimicrobial Resistance- Associated Genes in Citrobacter Freundii Isolated from Patients with Urinary Tract Infection in Al-Najaf Governorate-Iraq
}

\author{
${ }^{1}$ Thualfakar Hayder and ${ }^{2}$ Ahmed Abduljabbar Jaloob Aljanaby \\ ${ }^{I}$ Altoosi Collage University, Al-Najaf Governorate, Iraq \\ ${ }^{2}$ Department of Biology, Faculty of Science, University of Kufa, Iraq
}

Article history

Received: 11-04-2019

Revised: $10-05-2019$

Accepted: 25-06-2019

Corresponding Author:

Thualfakar Hayder

Altoosi Collage University, AlNajaf Governorate, Iraq

E-mail:

hualfakarhh.edu11p@uokufa.edu.iq ahmedaj.aljanabi@uokufa.edu.iq

\begin{abstract}
Citrobacter freundii is one of the most important pathogens that cause urinary tract infection in human because it harbors many types of antimicrobials resistance-associated genes. Therefore, this study aimed to evaluate the prevalence of antimicrobial resistance-associated genes citrobacter freundii isolated from patients with urinary tract infection in AlNajaf governorate-Iraq. A total of 30 strains of citrobacter freundii isolated from urine samples of patients with urinary tract infection in Al-Najaf central hospital in Al-Najaf City, Iraq, during April to December 2018. Polymers chain reaction technique was used to detect the presence of antimicrobial resistance-associated genes. From the 30 strains of citrobacter freundii, 15 strains (50\%) were positive for bla-tem gene, 16 strains $(53.3 \%)$ were positive for bla-shv gene, 21 strains (70\%) were positive for bla-ctxm gene, 3 strains (10\%) were positive for bla-ctxm-1 gene, 6 strains (20\%) were positive for bla-ctxm-2 gene. Interestingly, it should be noted that no any strain form the 30 we tested was carrying pse1, bla-ctxm-8, bla-ctxm-9 or bla-ctxm-25 genes. Our data showed that 19 strains (63.3\%) were positive for cat 1 gene, 9 strains (30\%) were positive for cat 2 gene and 4 strains $(13.3 \%)$ were positive for cat3 gene. On the other hand, 17 strains $(56.6 \%)$ were

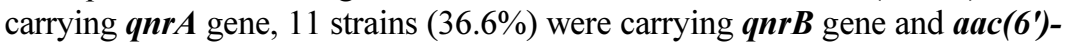
Ib-cr gene. Also, the results proved that there were 7 strains $(23.3 \%)$ being positive for sull gene and 11 strains $(36.6 \%)$ were positive for sul 2 gene. We also found 22 strains (73.3\%) being positive for strA-strB gene and 4 isolates (13.3\%) were positive for a $\boldsymbol{a c} \boldsymbol{C} \mathbf{1}$ genes. No strain carrying a $\boldsymbol{a c} \boldsymbol{C} \mathbf{2}$, tet $\boldsymbol{A}$ and tetB genes was identified. Citrobacter freundii harbor large numbers of different antimicrobial resistance-associated genes that enable this pathogen to escape the effect of antibiotics which make this bacteria highly resistant causing urinary tract infection.
\end{abstract}

Keywords: Citrobacter Freundii, Urinary Tract Infection, Antimicrobials Resistance-Associated Genes, Iraq

\section{Introduction}

Citrobacter freundii is consider as one of a commensal types of the intestinal tract of humans and different creatures but can also be found in water, sewage, food and hospital settings (Liu et al., 2018). Citrobacter freundii is a Gram-negative, facultative anaerobic, encapsulated motile organism with long rod shape, a typical length of bacterium is 1-5 $\mu \mathrm{m}$ (Hossain et al., 2017; Aljanaby and Aljanaby, 2017).
Citrobacter freundii is often found in clinical specimens as an opportunistic pathogen was implicated with infections that are generally resstricted to infants and immuno-compromised people (Plakkal et al., 2013; Bae et al., 2018). Citrobacter freundii responsible for nosocomial infection, blood stream and wounds infections, gastroenteritis, endocarditis, pneumonia, septicemia, urinary tract infection meningitis and brain abscesses with high mortality and morbidity (Aljanaby and Gafil, 2013). Citrobacter freundii has many types of 
antimicrobial resistance-associated genes such as $s h v, t e m$, $c t x-m$ and others enable this pathogen to escape the effect of various antibiotics, thus became more virulent and cause different types of infection such as urinary tract infection (Liu et al., 2017; 2018). In Iraq, there are limited studies focusing on the prevalence of antimicrobial resistance-associated genes in Citrobacter freundii isolated from patients with urinary tract infection. Therefore, the aim of this study was to investigate the prevalence of antimicrobial resistanceassociated genes in Citrobacter freundii isolated from patients with urinary tract infection. This study will draw a good genotypic picture of this pathogen.

\section{Materials and Methods}

\section{Study Design and Patients}

This is a cross-sectional descriptive study, performed in Al-Najaf central hospital in Al-Najaf City, Iraq, during period from April to December 2018. A total of 461 urine samples were collected from patients infected with urinary tract infection, females (21) and males (9), age groups between 18 to 60 years old.

\section{Eligibility Criteria for Patients}

Patients will be considered eligible for registration into this study if they fulfill all the inclusion criteria and none of the exclusion criteria as defined below:

1. Patients (female or male) at least equal or more than 18 years old

2. All infected patients have been diagnosis by physician and primary microscopic characters such as the presence of pus cells in urine samples

3. Patients should have sufficient capacity for informed consent

4. Patients should don't have any other infection

5. Patients should don't take any antibiotics for treatment

\section{Samples Collection, Culture and Bacterial Identification}

Ten $\mathrm{ml}$ of mid-stream urine samples were collected in sterile disposable containers after cleaned the genitals. All urine samples were centrifuged at $2000 \mathrm{rpm}$ for $5 \mathrm{~min}$, immediately, the sediment incubated aerobically with brain hart infusion broth at $37^{\circ} \mathrm{C}$ for $24 \mathrm{~h}$ then streaked with sterile loop on to blood agar and MacConkey agar (Oxoid ${ }^{\mathrm{TM}}$ ) plates (Mac Faddin, 2000). Colony Forming Units (CFUs) method was used for growing single and pure bacterial colony; all urine samples containing less than $10^{5} \mathrm{CFUs} / \mathrm{ml}$ were excluded (Tan et al., 2012). All emerged bacterial isolates were identified according to colony morphology and standard microbiological tests such as; colony morphology, Gram stain, oxidase test, catalase test, imvic test, motility test, coagulase test, growth on MacConkey agar $\left(\right.$ Oxoid $^{\mathrm{TM}}$ ) (Mac Faddin, 2000).

DNA extraction: The previously published protocol (Yang et al., 2008) was used for the extraction of total DNA as follows: Five pure and fresh colonies of citrobacter freundii strains were suspended in $200 \mu \mathrm{l}$ of sterile deionized water and cells were placed in water bath (Memmert-Germany) at $100^{\circ} \mathrm{C}$ for $30 \mathrm{~min}$, immediately the solution was placed in ice for $30 \mathrm{~min}$ and the other cellular components was removed by centrifugation at $9000 \mathrm{rpm}$ for $15 \mathrm{~min}$. Finally the supernatant was used as the DNA template.

Polymerase Chain Reaction (PCR) detection of antimicrobials resistance-associated genes: Polymerase chain reaction was used to detect 22 antimicrobials resistance-associated genes: All primers used in this study and all PCR thermo cycling conditions are listed in Tables 1 and 2, respectively. All PCR products were loaded on a $1.5 \%(\mathrm{w} / \mathrm{v})$ agarose gel with $0.5 \mathrm{mg} / \mathrm{mL}$ safestain and were analyzed by gel electrophoresis. All primers used in this study and all PCR thermo cycling conditions are listed in Tables 1 and 2, respectively.

Table 1: Sequencing of primers used in PCR for 22 antimicrobials resistance-associated genes of citrobacter freundii

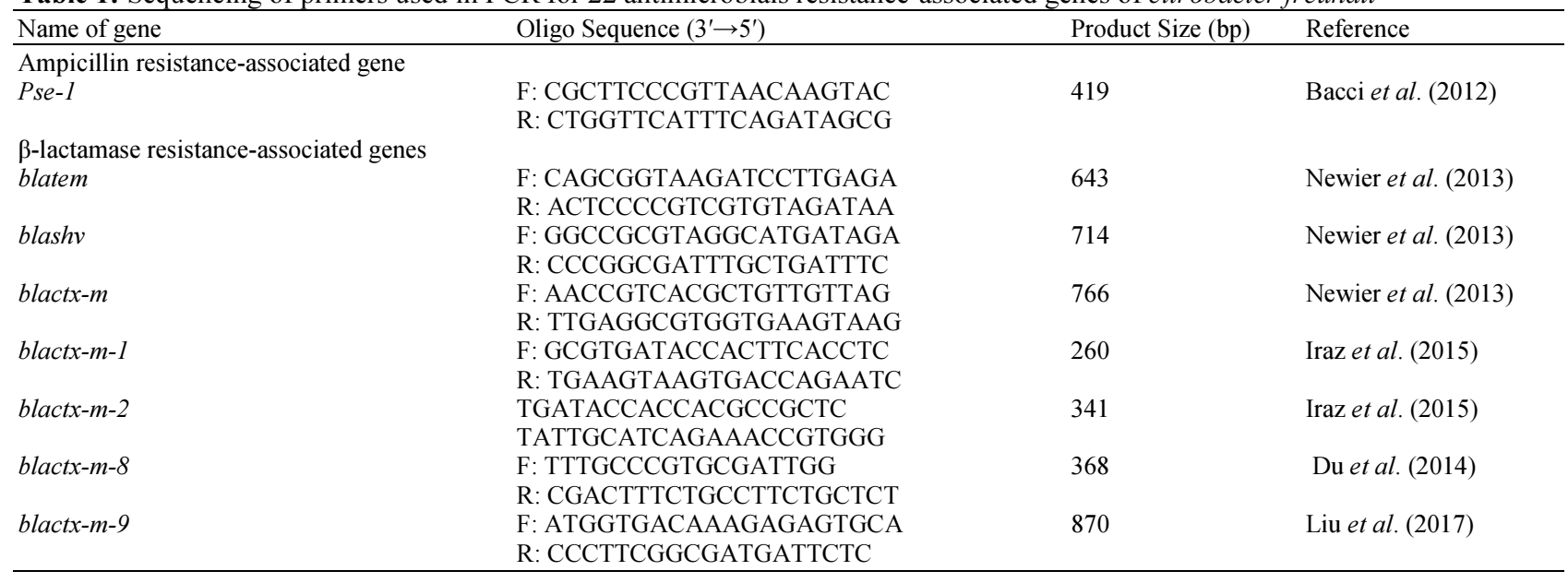


Table 1: Continue

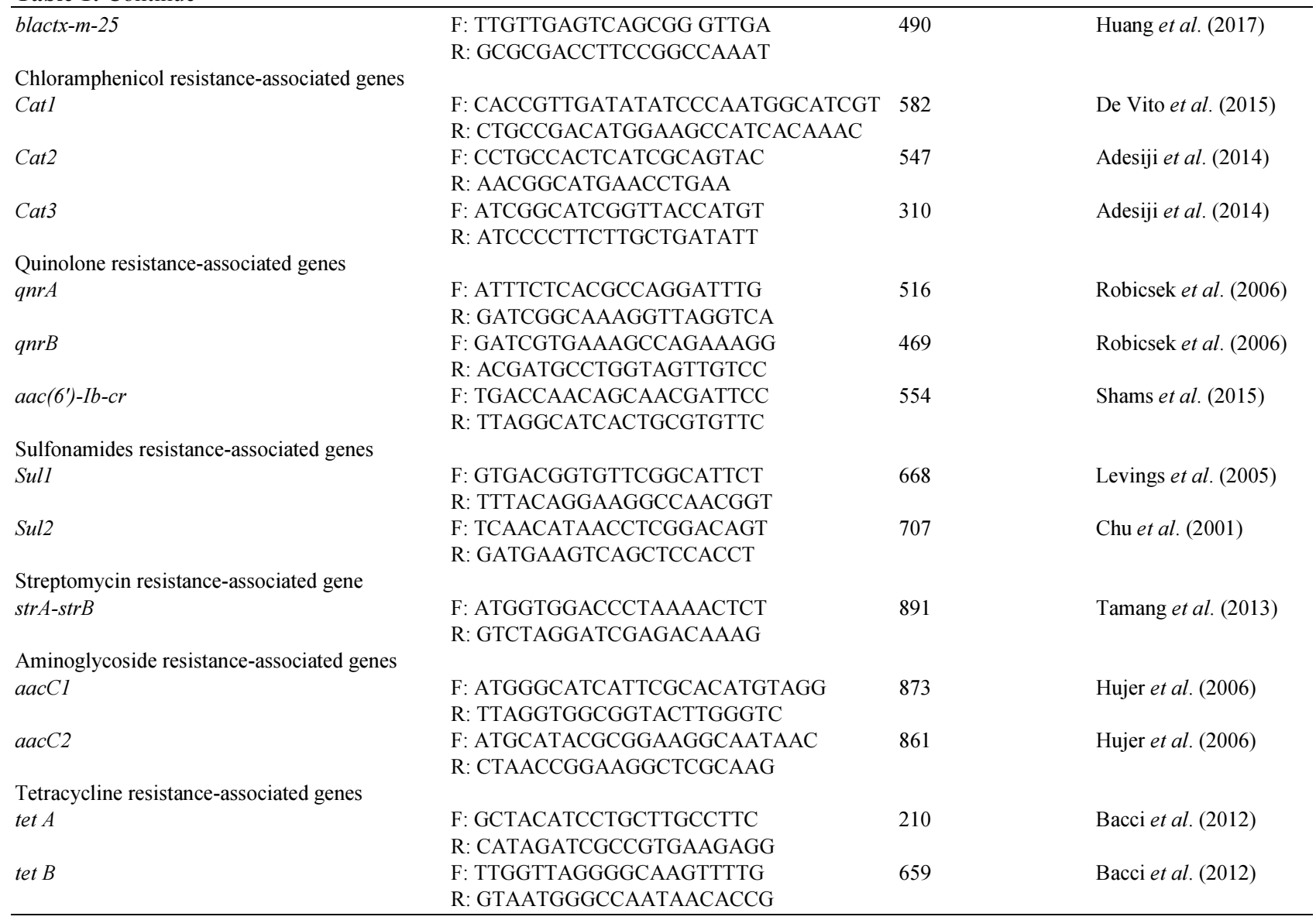

Table 2: Thermo cycling conditions of PCR for 22 antimicrobials resistance-associated genes of Citrobacter freundii Cycling condition ${ }^{\circ} \mathrm{C} /$ Time

\begin{tabular}{|c|c|c|c|c|c|c|c|}
\hline Gene & $\begin{array}{l}\text { Initial } \\
\text { denaturation } \\
{ }^{\circ} \mathrm{C}_{/} \text {Time }\end{array}$ & Denaturation & Annealing & Extension & N Cycles & $\begin{array}{l}\text { Final } \\
\text { extension } \\
{ }^{\circ} \mathrm{C} / \text { Time } \\
\end{array}$ & Reference \\
\hline Pse-1 & $94^{\circ} \mathrm{C} / 12 \mathrm{~min}$ & $94^{\circ} \mathrm{C} / 1 \mathrm{~min}$ & $57^{\circ} \mathrm{C} / 30 \mathrm{sec}$ & $72^{\circ} \mathrm{C} / 5 \mathrm{~min}$ & 34 & $72^{\circ} \mathrm{C} / 7 \mathrm{~min}$ & Bacci et al. (2012) \\
\hline bla-tem & $95^{\circ} \mathrm{C} / 5 \mathrm{~min}$ & $94^{\circ} \mathrm{C} / 30 \mathrm{sec}$ & $52^{\circ} \mathrm{C} / 45 \mathrm{sec}$ & $72^{\circ} \mathrm{C} / 45 \mathrm{sec}$ & 30 & $72^{\circ} \mathrm{C} / 7 \mathrm{~min}$ & Newier et al. (2013) \\
\hline bla-shv & $95^{\circ} \mathrm{C} / 5 \mathrm{~min}$ & $94^{\circ} \mathrm{C} / 30 \mathrm{sec}$ & $55^{\circ} \mathrm{C} / 60 \mathrm{sec}$ & $72^{\circ} \mathrm{C} / 45 \mathrm{sec}$ & 30 & $72^{\circ} \mathrm{C} / 7 \mathrm{~min}$ & Newier et al. (2013) \\
\hline blactx-m & $95^{\circ} \mathrm{C} / 5 \mathrm{~min}$ & $94^{\circ} \mathrm{C} / 30 \mathrm{sec}$ & $57^{\circ} \mathrm{C} / 45 \mathrm{sec}$ & $72^{\circ} \mathrm{C} / 45 \mathrm{sec}$ & 30 & $72^{\circ} \mathrm{C} / 7 \mathrm{~min}$ & Newier et al. (2013) \\
\hline blactx-m-1 & $94^{\circ} \mathrm{C} / 4 \mathrm{~min}$ & $94^{\circ} \mathrm{C} / 1 \mathrm{~min}$ & $54^{\circ} \mathrm{C} / 60 \mathrm{sec}$ & $72^{\circ} \mathrm{C} / 1 \mathrm{~min}$ & 30 & $72^{\circ} \mathrm{C} / 10 \mathrm{~min}$ & Iraz et al. (2015) \\
\hline blactx-m-2 & $95^{\circ} \mathrm{C} / 5 \mathrm{~min}$ & $95^{\circ} \mathrm{C} / 50 \mathrm{sec}$ & $56^{\circ} \mathrm{C} / 40 \mathrm{sec}$ & $72^{\circ} \mathrm{C} / 60 \mathrm{sec}$ & 35 & $72^{\circ} \mathrm{C} / 5 \mathrm{~min}$ & Iraz et al. (2015) \\
\hline blactx-m-8 & $95^{\circ} \mathrm{C} / 5 \mathrm{~min}$ & $95^{\circ} \mathrm{C} / 50 \mathrm{sec}$ & $50^{\circ} \mathrm{C} / 40 \mathrm{sec}$ & $72^{\circ} \mathrm{C} / 60 \mathrm{sec}$ & 35 & $72^{\circ} \mathrm{C} / 5 \mathrm{~min}$ & Du et al. (2014) \\
\hline blact $x-m-9$ & $95^{\circ} \mathrm{C} / 5 \mathrm{~min}$ & $95^{\circ} \mathrm{C} / 50 \mathrm{sec}$ & $50^{\circ} \mathrm{C} / 40 \mathrm{sec}$ & $72^{\circ} \mathrm{C} / 60 \mathrm{sec}$ & 35 & $72^{\circ} \mathrm{C} / 5 \mathrm{~min}$ & Liu et al. (2017) \\
\hline blact $x-m-25$ & $94^{\circ} \mathrm{C} / 5 \mathrm{~min}$ & $94^{\circ} \mathrm{C} / 25 \mathrm{sec}$ & $53^{\circ} \mathrm{C} / 40 \mathrm{sec}$ & $72^{\circ} \mathrm{C} / 60 \mathrm{sec}$ & 30 & $72^{\circ} \mathrm{C} / 6 \mathrm{~min}$ & Huang et al. (2017) \\
\hline Cat1 & $95^{\circ} \mathrm{C} / 5 \mathrm{~min}$ & $94^{\circ} \mathrm{C} / 30 \mathrm{sec}$ & $62^{\circ} \mathrm{C} / 45 \mathrm{sec}$ & $72^{\circ} \mathrm{C} / 5 \mathrm{~min}$ & 30 & $72^{\circ} \mathrm{C} / 7 \mathrm{~min}$ & De Vito et al. (2015) \\
\hline Cat2 & $95^{\circ} \mathrm{C} / 5 \mathrm{~min}$ & $94^{\circ} \mathrm{C} / 30 \mathrm{sec}$ & $55^{\circ} \mathrm{C} / 30 \mathrm{sec}$ & $72^{\circ} \mathrm{C} / 30 \mathrm{sec}$ & 35 & $72^{\circ} \mathrm{C} / 10 \mathrm{~min}$ & Adesiji et al. (2014) \\
\hline Cat3 & $95^{\circ} \mathrm{C} / 5 \mathrm{~min}$ & $94^{\circ} \mathrm{C} / 30 \mathrm{sec}$ & $55^{\circ} \mathrm{C} / 30 \mathrm{sec}$ & $72^{\circ} \mathrm{C} / 30 \mathrm{sec}$ & 35 & $72^{\circ} \mathrm{C} / 10 \mathrm{~min}$ & Adesiji et al. (2014) \\
\hline$q n r A$ & $95^{\circ} \mathrm{C} / 5 \mathrm{~min}$ & $94^{\circ} \mathrm{C} / 1 \mathrm{~min}$ & $55^{\circ} \mathrm{C} / 1 \mathrm{~min}$ & $72^{\circ} \mathrm{C} / 2 \mathrm{~min}$ & 30 & $72^{\circ} \mathrm{C} / 5 \mathrm{~min}$ & Robicsek et al. (2006) \\
\hline$q n r B$ & $95^{\circ} \mathrm{C} / 5 \mathrm{~min}$ & $94^{\circ} \mathrm{C} / 1 \mathrm{~min}$ & $55^{\circ} \mathrm{C} / 1 \mathrm{~min}$ & $72^{\circ} \mathrm{C} / 2 \mathrm{~min}$ & 30 & $72^{\circ} \mathrm{C} / 5 \mathrm{~min}$ & Robicsek et al. (2006) \\
\hline$a a c\left(6^{\prime}\right)-I b-c r$ & $95^{\circ} \mathrm{C} / 5 \mathrm{~min}$ & $94^{\circ} \mathrm{C} / 1 \mathrm{~min}$ & $55^{\circ} \mathrm{C} / 1 \mathrm{~min}$ & $72^{\circ} \mathrm{C} / 2 \mathrm{~min}$ & 30 & $72^{\circ} \mathrm{C} / 5 \mathrm{~min}$ & Shams et al. (2015) \\
\hline Sull & $95^{\circ} \mathrm{C} / 5 \mathrm{~min}$ & $94^{\circ} \mathrm{C} / 2 \mathrm{~min}$ & $53^{\circ} \mathrm{C} / 1 \mathrm{~min}$ & $72^{\circ} \mathrm{C} / 30 \mathrm{sec}$ & 35 & $72^{\circ} \mathrm{C} / 7 \mathrm{~min}$ & Levings et al. (2005) \\
\hline Sul2 & $94^{\circ} \mathrm{C} / 5 \mathrm{~min}$ & $94^{\circ} \mathrm{C} / 1 \mathrm{~min}$ & $50^{\circ} \mathrm{C} / 1 \mathrm{~min}$ & $72^{\circ} \mathrm{C} / 1 \mathrm{~min}$ & 32 & $72^{\circ} \mathrm{C} / 7 \mathrm{~min}$ & Chu et al. (2001) \\
\hline $\operatorname{str} A-s t r B$ & $94^{\circ} \mathrm{C} / 2 \mathrm{~min}$ & $94^{\circ} \mathrm{C} / 60 \mathrm{sec}$ & $55^{\circ} \mathrm{C} / 60 \mathrm{sec}$ & $72^{\circ} \mathrm{C} / 60 \mathrm{sec}$ & 30 & $72^{\circ} \mathrm{C} / 5 \mathrm{~min}$ & Tamang et al. (2013) \\
\hline $\operatorname{aacCl}$ & $95^{\circ} \mathrm{C} / 5 \mathrm{~min}$ & $94^{\circ} \mathrm{C} / 1 \mathrm{~min}$ & $55^{\circ} \mathrm{C} / 1 \mathrm{~min}$ & $72^{\circ} \mathrm{C} / 2 \mathrm{~min}$ & 30 & $72^{\circ} \mathrm{C} / 5 \mathrm{~min}$ & Hujer et al. (2006) \\
\hline $\operatorname{aacC} 2$ & $95^{\circ} \mathrm{C} / 5 \mathrm{~min}$ & $94^{\circ} \mathrm{C} / 1 \mathrm{~min}$ & $55^{\circ} \mathrm{C} / 1 \mathrm{~min}$ & $72^{\circ} \mathrm{C} / 2 \mathrm{~min}$ & 30 & $72^{\circ} \mathrm{C} / 5 \mathrm{~min}$ & Hujer et al. (2006) \\
\hline tetA & $94^{\circ} \mathrm{C} / 5 \mathrm{~min}$ & $94^{\circ} \mathrm{C} / 25 \mathrm{sec}$ & $55^{\circ} \mathrm{C} / 30 \mathrm{sec}$ & $72^{\circ} \mathrm{C} / 50 \mathrm{sec}$ & 34 & $72^{\circ} \mathrm{C} / 5 \mathrm{~min}$ & Bacci et al. (2012) \\
\hline tet $B$ & $94^{\circ} \mathrm{C} / 5 \mathrm{~min}$ & $94^{\circ} \mathrm{C} / 25 \mathrm{sec}$ & $55^{\circ} \mathrm{C} / 30 \mathrm{sec}$ & $72^{\circ} \mathrm{C} / 50 \mathrm{sec}$ & 34 & $72^{\circ} \mathrm{C} / 5 \mathrm{~min}$ & Bacci et al. (2012) \\
\hline
\end{tabular}


Statistical Analysis: Fisher's exact test was used in this study for the comparison between samples by using SPSS version 6 software. P values less than the 0.05 level of significance were considered statistically significant (Aljanaby and Gafil, 2013).

\section{Results}

\section{Beta Lactamase Resistance Associated Genes}

Out of 30 isolates, there were 15 isolates (50\%) were positive for bla-tem gene (Fig. 1), 16 isolates $(53.3 \%)$ were positive for bla-shv gene (Fig. 2), 21 isolates $(70 \%)$ were positive for bla-ctxm gene (Fig. 3 ), 3 isolates (10\%) were positive for bla-ctxm-1 gene (Fig. 4), 6 isolates (20\%) were positive for bla-ctxm-2 gene (Fig. 5). We did not detect any isolate carrying pse1, bla-ctxm-8, bla-ctxm-9 and bla-ctxm-25 genes.

\section{Chloramphenicol Resistance Associated Genes}

In this study, 3 genes were selected as a chloramphenicol resistance associated genes, the results proved that there were 19 isolates (63.3\%) positive for cat 1 gene (Fig. 6), 9 isolates (30\%) were positive for cat 2 gene (Fig. 7) and 4 isolates (13.3\%) were positive for cat3 gene (Fig. 8).

\section{Quinolones Resistance Associated Genes}

The results indicated that 17 isolates $(56.6 \%)$ were carrying qnrA gene (Fig. 9), 11 isolates (36.6\%) were carrying $q n r B$ gene (Fig. 10) and aac(6')-Ib-cr gene (Fig. 11).

\section{Sulfonamide Resistance Associated Genes}

In the current study, genotypic detection of two genes that responsible for encoding sulfonamide resistance associated genes: sul 1 and sul2 were detected by Polymerase chain reaction using specific primer sequences which yield products size $668 \mathrm{bp}$ and $707 \mathrm{bp}$ respectively. The results proved that there were 7 isolates (23.3\%) positive for sul1 (Fig. 12) and 11 isolates (36.6\%) were positive for sul2 gene (Fig. 13).

\section{Streptomycin, Aminoglycoside and Tetracycline Resistance Associated Genes}

Different genes were used to detect the prevalence of Streptomycin, aminoglycoside and tetracycline resistance associated genes in 30 isolates of Citrobacter freundii. $\operatorname{str} A-\operatorname{str} B$ gene was used as a streptomycin resistance associated genes, the results showed that there were 22 isolates $(73.3 \%)$ were positive for $\operatorname{str} A$ $s t r B$ gene (Fig. 14). aacC1 and aacC2 genes were used as a aminoglycoside resistance associated genes, the results indicated that there were 4 isolates $(13.3 \%)$ were positive for aacClgene (Fig. 15) while, there was no any isolates was carrying aacC2 gene. tet $A$ and $t e t B$ genes were used as a tetracycline resistance associated genes, the results proved that there was no any isolate was carrying these genes. All numbers and percentages of antimicrobials resistance associated genes in Citrobacter freundii isolates are mentioned in Fig. 16 and Table 3.

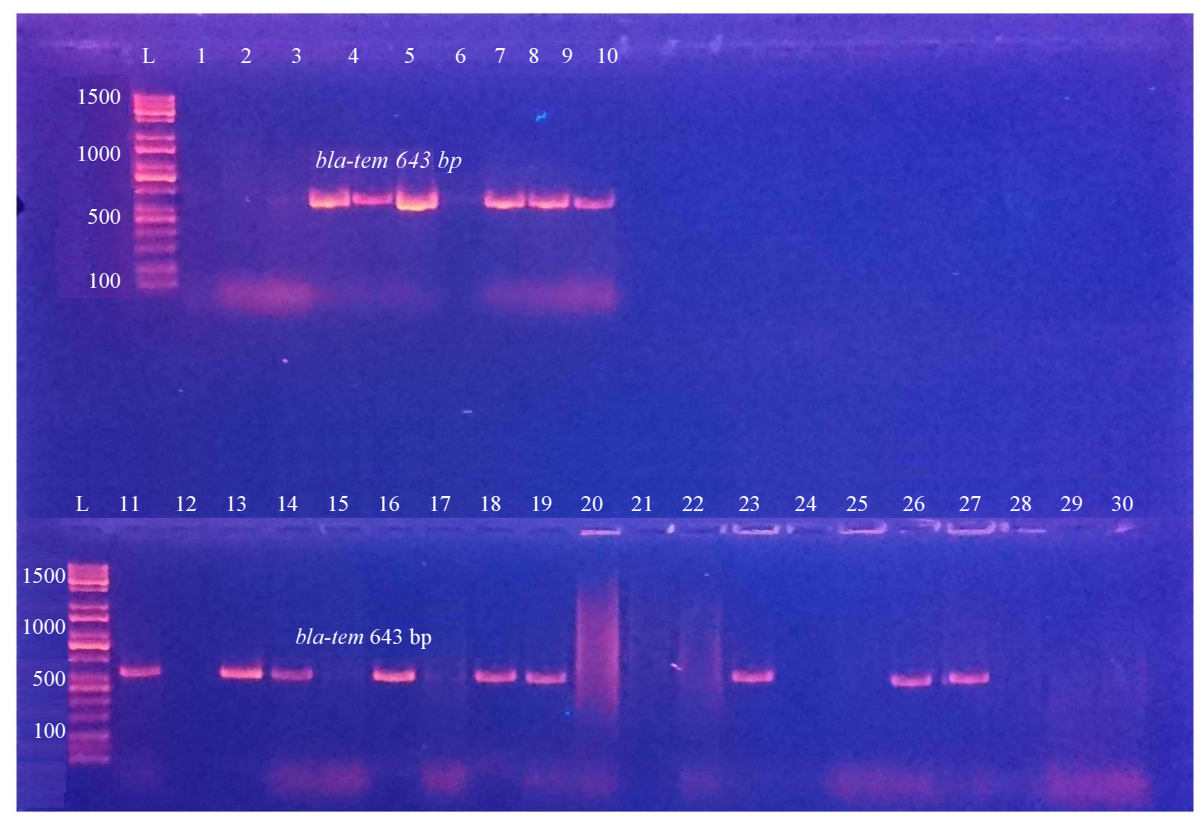

Fig. 1: Polymerase chain reaction amplified products from extracted DNA of 30 Citrobacter freundii isolates. Amplified with blatem gene show positive results at 643 bp. The electrophoresis was performed at 90 volt for 90 minutes. L: DNA molecular size marker $100 \mathrm{bp}$. (ladder: 100 to $1500 \mathrm{bp}$ ) 


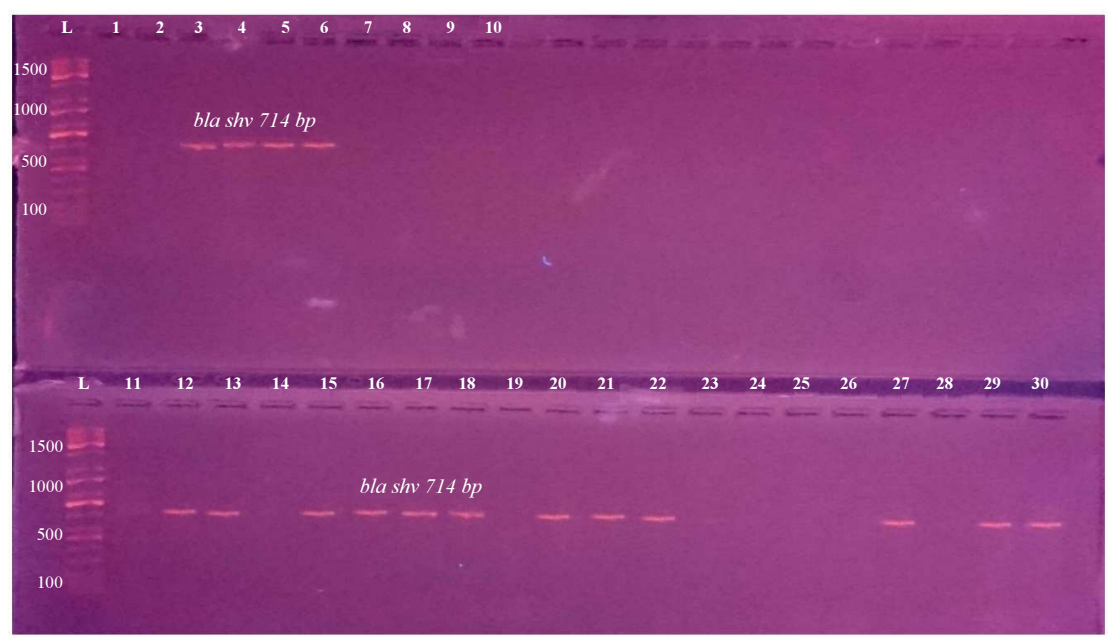

Fig. 2: Polymerase chain reaction amplified products from extracted DNA of 30 Citrobacter freundii isolates. Amplified with bla$s h v$ gene show positive results at $714 \mathrm{bp}$. The electrophoresis was performed at 90 volt for 90 minutes. L: DNA molecular size marker $100 \mathrm{bp}$. (ladder: 100 to $1500 \mathrm{bp}$ )

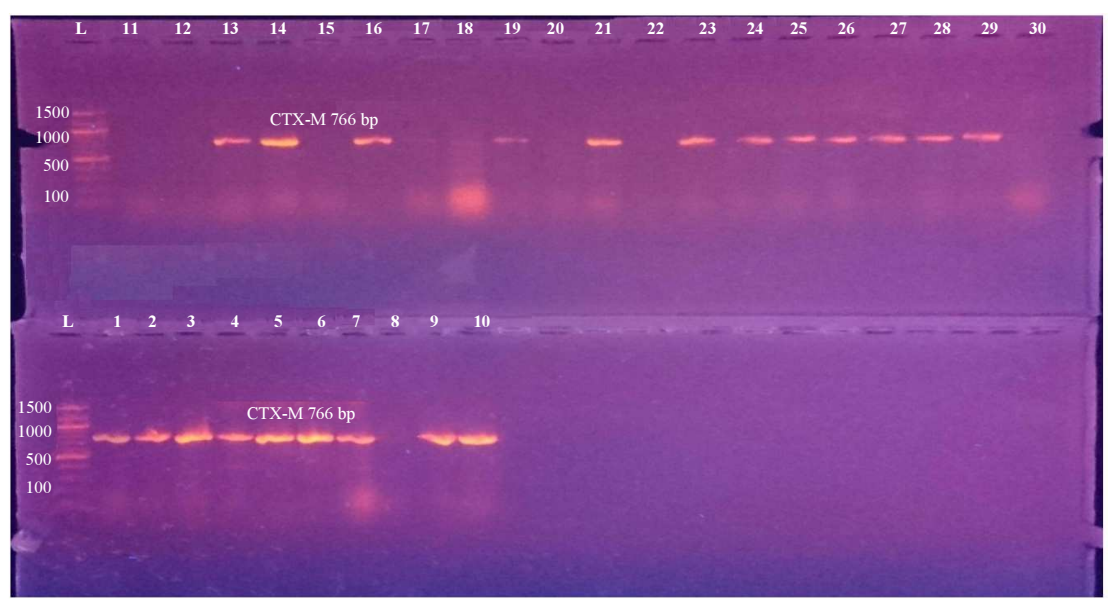

Fig. 3: Polymerase chain reaction amplified products from extracted DNA of 30 Citrobacter freundii isolates. Amplified with bla$c t x-m$ gene show positive results at $766 \mathrm{bp}$. The electrophoresis was performed at 90 volt for 90 minutes. L: DNA molecular size marker $100 \mathrm{bp}$. (ladder: 100 to $1500 \mathrm{bp}$ )

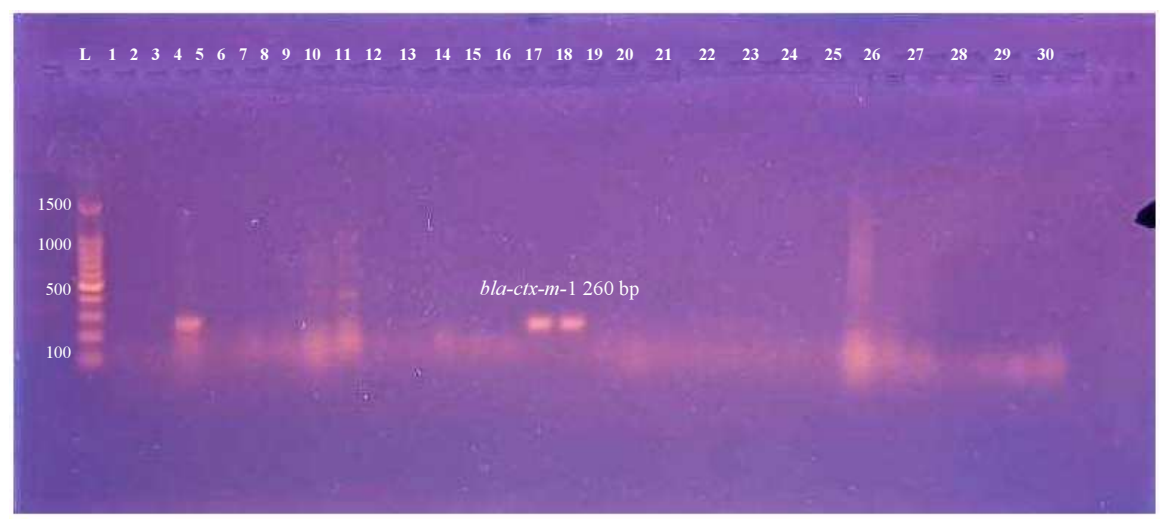

Fig. 4: Polymerase chain reaction amplified products from extracted DNA of 30 Citrobacter freundii isolates. Amplified with blactxm-1 gene show positive results at $260 \mathrm{bp}$. The electrophoresis was performed at 90 volt for 90 minutes. L: DNA molecular size marker 100 bp. (ladder: 100 to $1500 \mathrm{bp}$ ) 


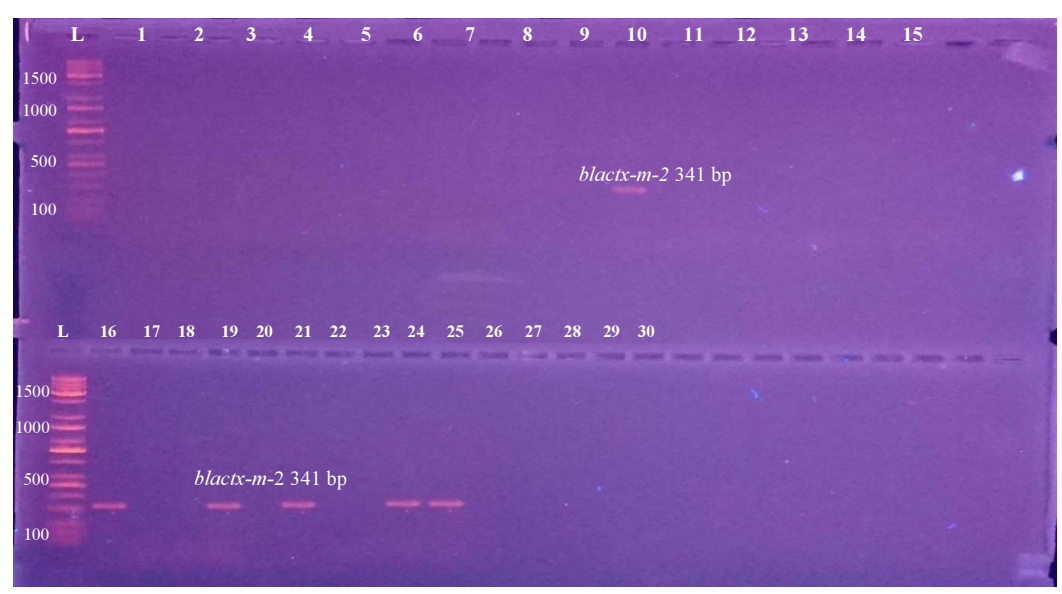

Fig. 5: Polymerase chain reaction amplified products from extracted DNA of 30 Citrobacter freundii isolates. Amplified with blactxm-2 gene show positive results at $341 \mathrm{bp}$. The electrophoresis was performed at 90 volt for 90 minutes. L: DNA molecular size marker $100 \mathrm{bp}$. (ladder: 100 to $1500 \mathrm{bp}$ )

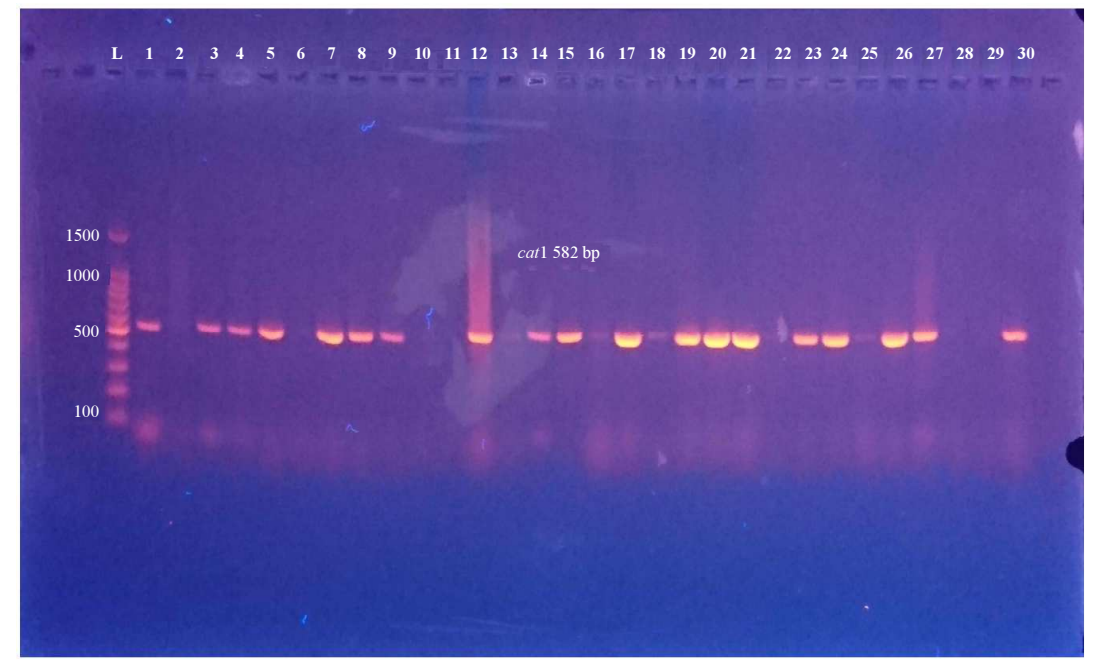

Fig. 6: Polymerase chain reaction amplified products from extracted DNA of 30 Citrobacter freundii isolates. Amplified with cat 1 gene show positive results at $582 \mathrm{bp}$. The electrophoresis was performed at 90 volt for 90 minutes. L: DNA molecular size marker $100 \mathrm{bp}$. (ladder: 100 to $1500 \mathrm{bp}$ )

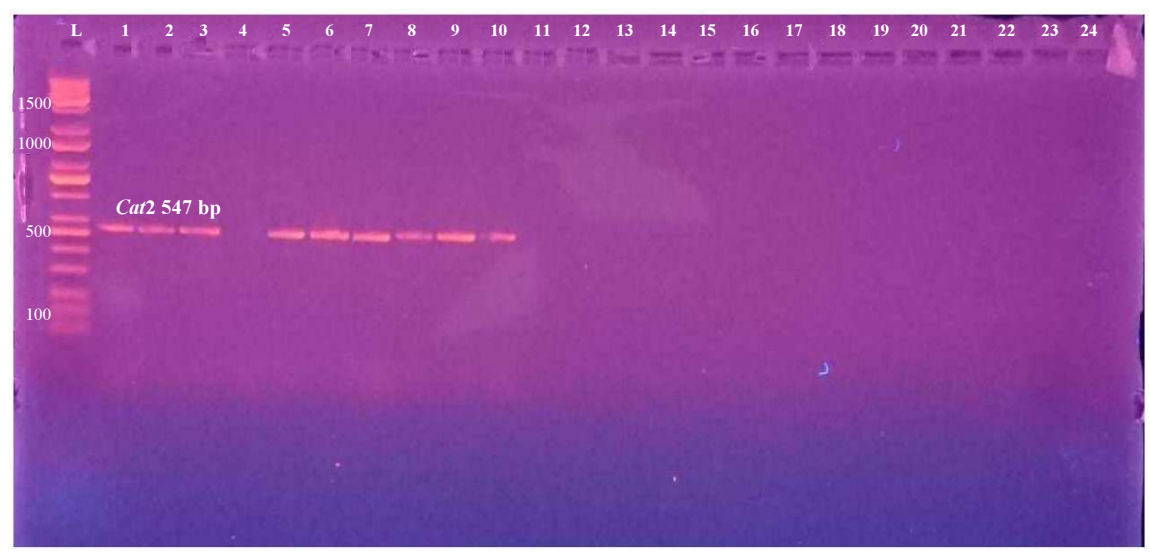

Fig. 7: Polymerase chain reaction amplified products from extracted DNA of 30 Citrobacter freundii isolates. Amplified with cat2 gene show positive results at $547 \mathrm{bp}$. The electrophoresis was performed at 90 volt for 90 minutes. L: DNA molecular size marker 100 bp. (ladder: 100 to $1500 \mathrm{bp}$ ) 


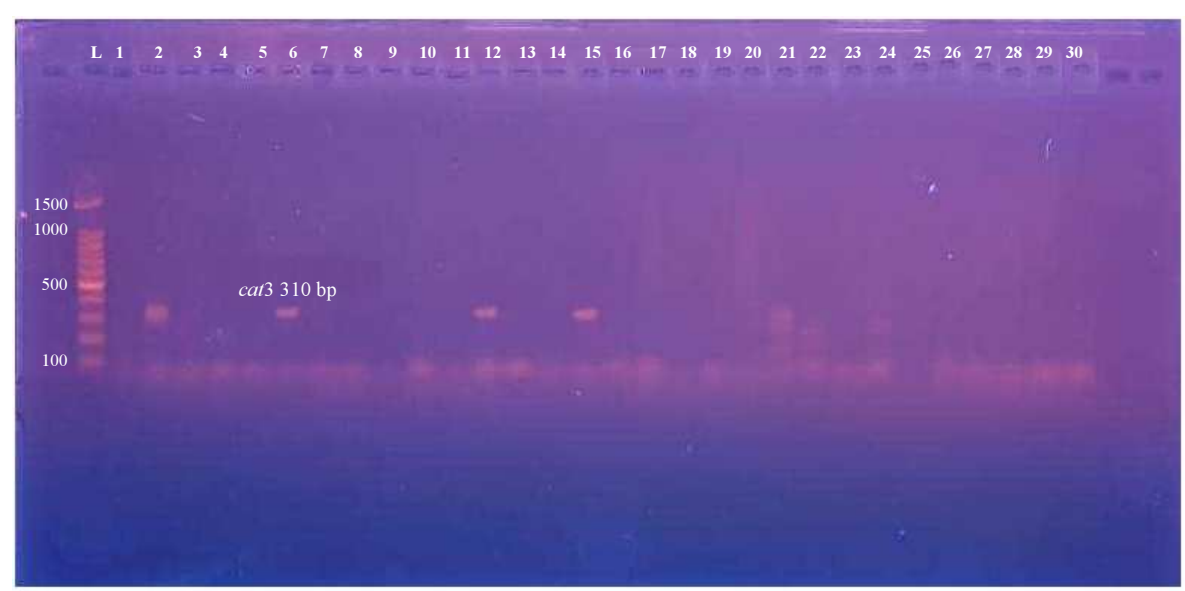

Fig. 8: Polymerase chain reaction amplified products from extracted DNA of 30 Citrobacter freundii isolates. Amplified with cat 3 gene show positive results at $310 \mathrm{bp}$. The electrophoresis was performed at 90 volt for 90 minutes. L: DNA molecular size marker 100 bp. (ladder: 100 to $1500 \mathrm{bp}$ )

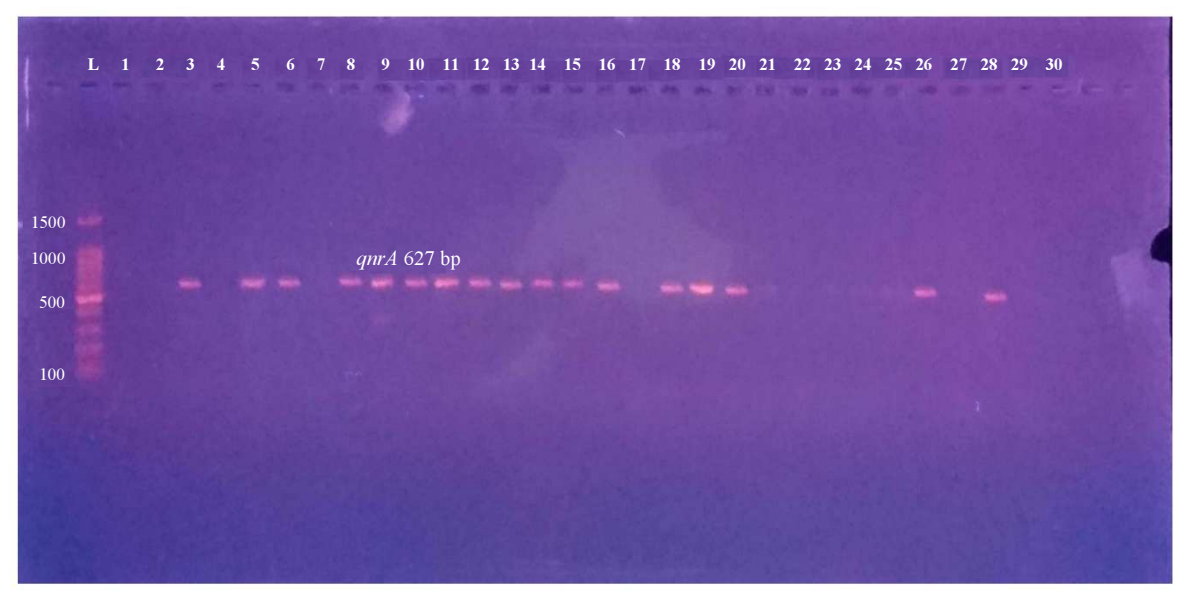

Fig. 9: Polymerase chain reaction amplified products from extracted DNA of 30 Citrobacter freundii isolates. Amplified with qnrA gene show positive results at $627 \mathrm{bp}$. The electrophoresis was performed at 90 volt for 90 minutes. L: DNA molecular size marker $100 \mathrm{bp}$. (ladder: 100 to $1500 \mathrm{bp}$ )

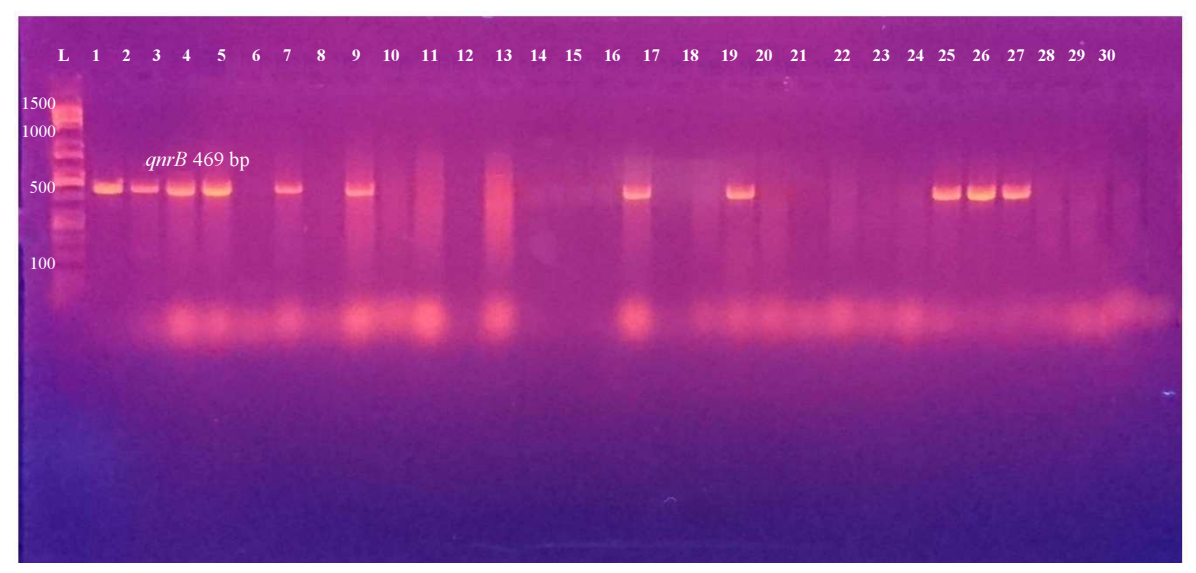

Fig. 10: Polymerase chain reaction amplified products from extracted DNA of 30 Citrobacter freundii isolates. Amplified with qnrB gene show positive results at $469 \mathrm{bp}$. The electrophoresis was performed at 90 volt for 90 minutes. L: DNA molecular size marker 100 bp. (ladder: 100 to $1500 \mathrm{bp}$ ) 


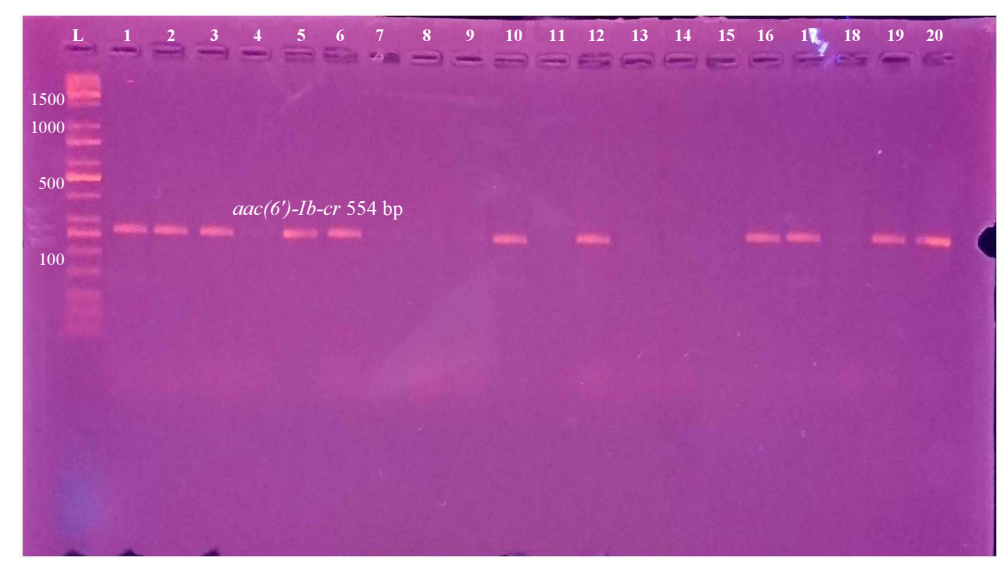

Fig. 11: Polymerase chain reaction amplified products from extracted DNA of Citrobacter freundii isolates. Amplified with aac(6')$\mathrm{Ib}-\mathrm{cr}$ gene show positive results at $554 \mathrm{bp}$. The electrophoresis was performed at 90 volt for 90 minutes. L: DNA molecular size marker $100 \mathrm{bp}$. (ladder: 100 to $1500 \mathrm{bp}$ )

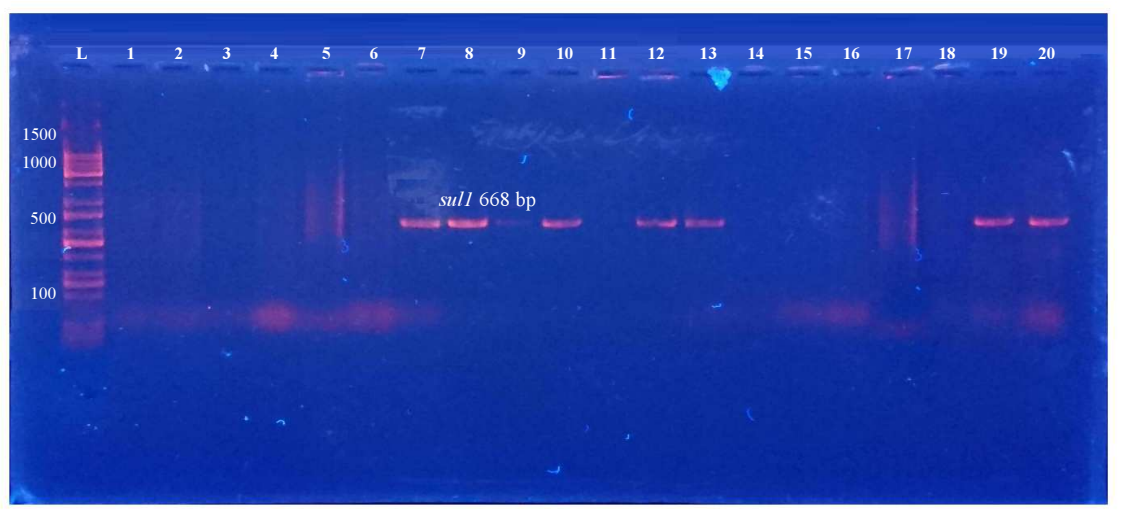

Fig. 12: Polymerase chain reaction amplified products from extracted DNA of Citrobacter freundii isolates. Amplified with sull gene show positive results at $668 \mathrm{bp}$. The electrophoresis was performed at 90 volt for 90 minutes. L: DNA molecular size marker $100 \mathrm{bp}$. (ladder: 100 to $1500 \mathrm{bp}$ )

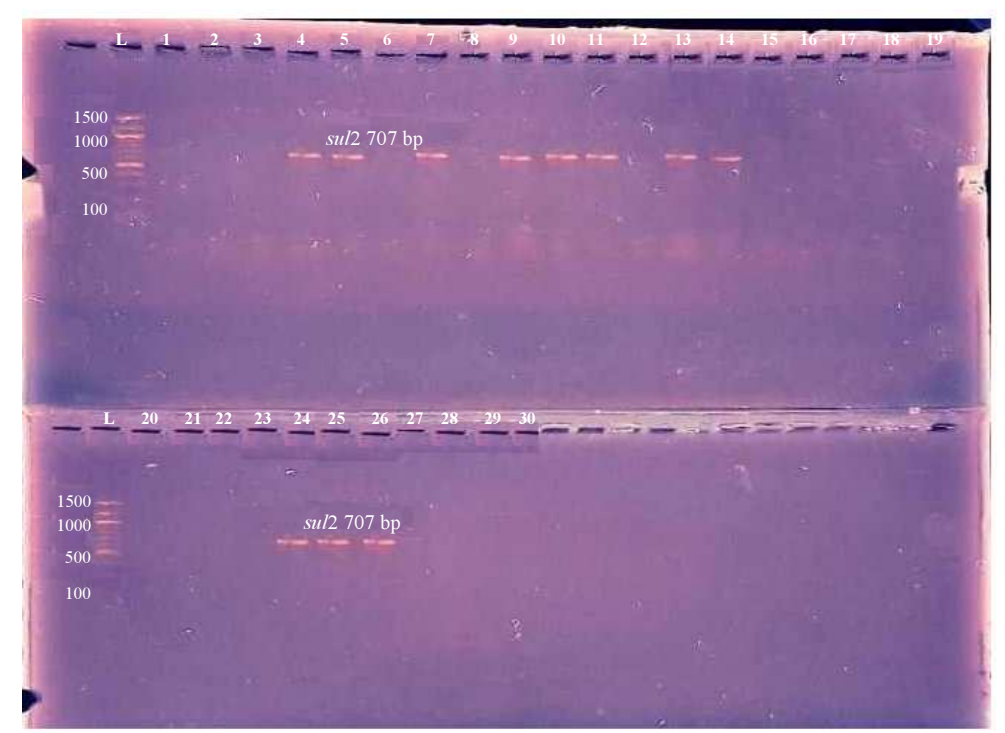

Fig. 13: Polymerase chain reaction amplified products from extracted DNA of 30 Citrobacter freundii isolates. Amplified with sul2 gene show positive results at $707 \mathrm{bp}$. The electrophoresis was performed at 90 volt for 90 minutes. L: DNA molecular size marker 100 bp. (ladder: 100 to $1500 \mathrm{bp}$ ) 


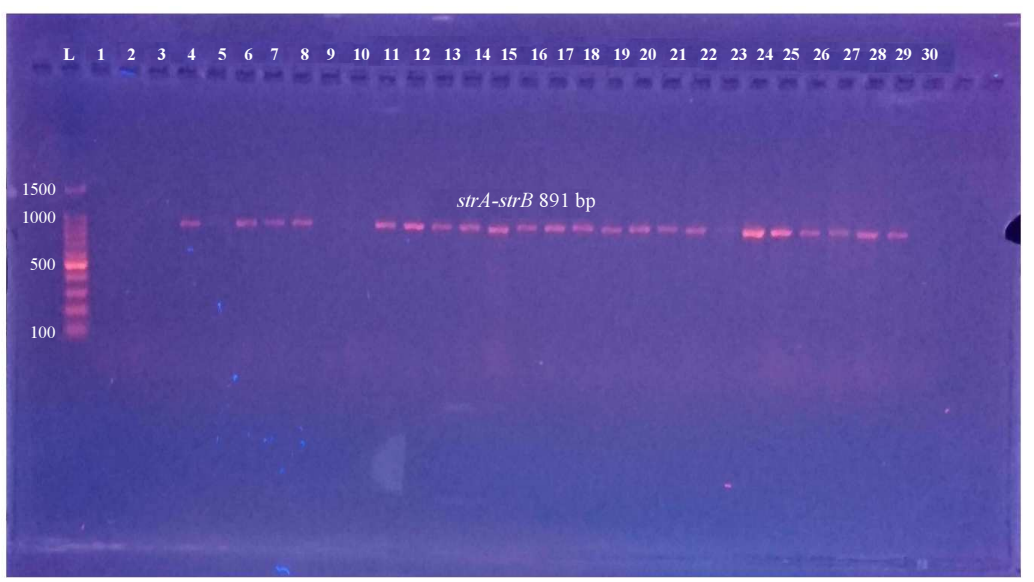

Fig. 14: Polymerase chain reaction amplified products from extracted DNA of 30 Citrobacter freundii isolates. Amplified with strA$s t r B$ gene show positive results at $891 \mathrm{bp}$. The electrophoresis was performed at 90 volt for 90 minutes. L: DNA molecular size marker $100 \mathrm{bp}$. (ladder: 100 to $1500 \mathrm{bp}$ )

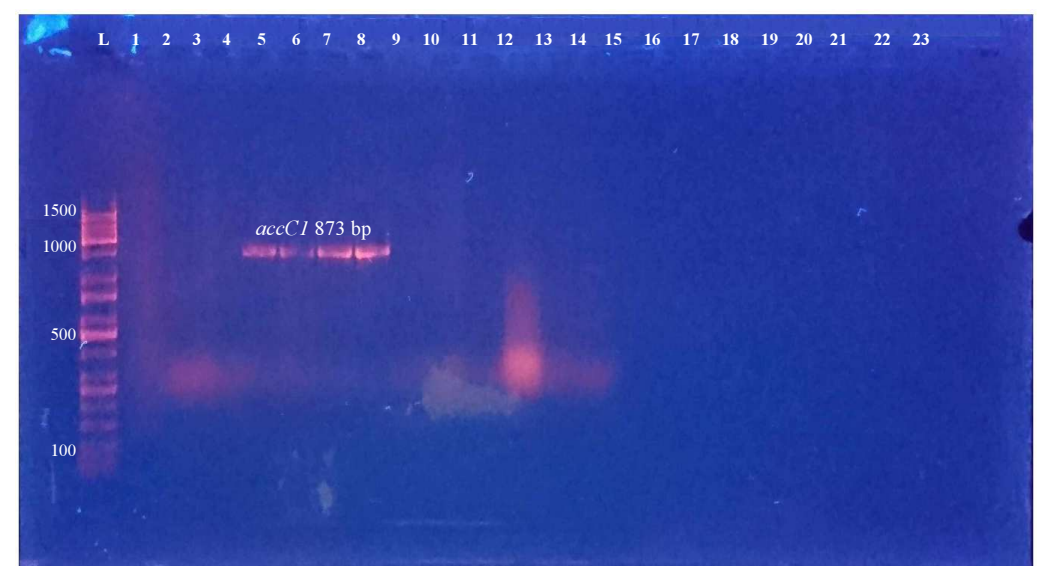

Fig. 15: Polymerase chain reaction amplified products from extracted DNA of Citrobacter freundii isolates. Amplified with accC1 gene show positive results at $873 \mathrm{bp}$. The electrophoresis was performed at 90 volt for 90 minutes. L: DNA molecular size marker $100 \mathrm{bp}$. (ladder: 100 to $1500 \mathrm{bp}$ )

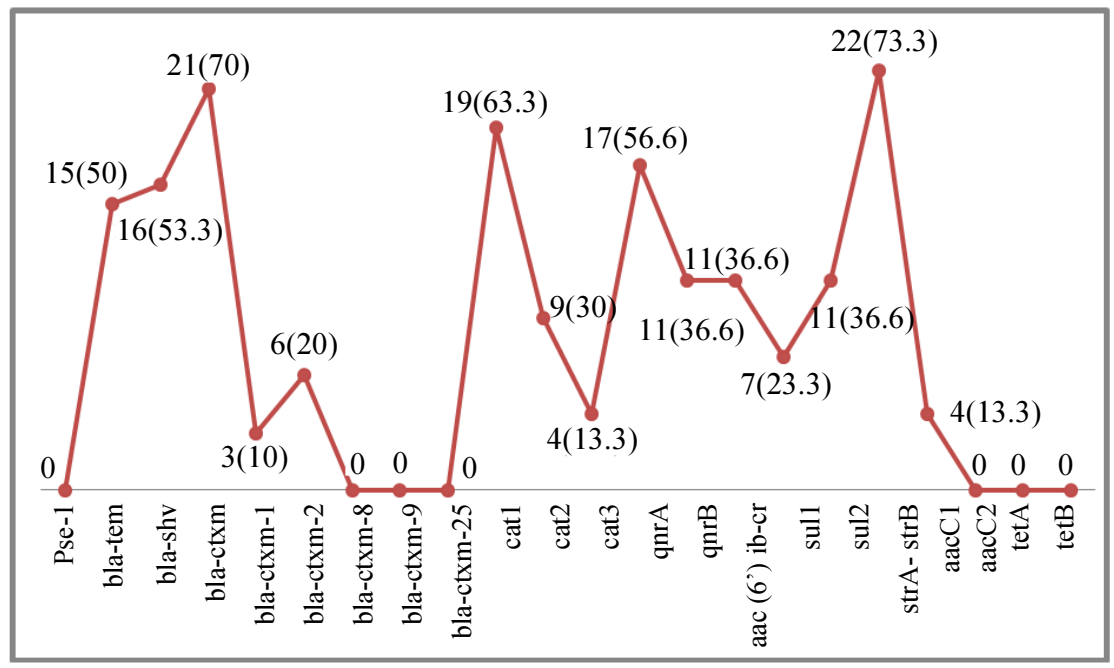

Fig. 16: Numbers and percentages (\%) of antimicrobials resistance associated genes in Citrobacter freundii isolates from patients infected with urinary tract infection in Al-Najaf City-Iraq during period from April to December 2018. $(\mathrm{N}=30)$ 
Table 3: Genotypic profile of resistance associated genes in 30 Citrobacter freundii isolates from patients infected with urinary tract infection in Al-Najaf City-Iraq during period from April to December 2018

\begin{tabular}{|c|c|c|c|c|}
\hline Isolate & Resistance associated genes & No. $(\%)$ & Gender & Age group \\
\hline 1 & cat 1, cat $2, q n r B, a a c\left(6^{\prime}\right)-I b-c r$ & $4(9.2)$ & F & $51-60$ \\
\hline 2 & $\operatorname{cat} 2$, Cat $3, \operatorname{gnr} B, a a c\left(6^{\prime}\right)-I b-c r$ & $4(9.2)$ & $\mathrm{F}$ & $18-30$ \\
\hline 3 & bla-shv, bla-ctxm, bla-ctxm-1, cat 1, cat 2, qnrA, qnrB, aac (6')-Ib-cr & $8(34.7)$ & $\mathrm{F}$ & $41-50$ \\
\hline 4 & bla-tem, bla-shv, bla-ctxm, cat 1, qnrB, sul2, strA-strB, aacCl & $8(34.7)$ & $\mathrm{F}$ & $31-40$ \\
\hline 5 & bla-tem, bla-shv, cat 1, cat 2, qnrA, aac(6')-Ib-cr, sul2, aacC1 & $8(34.7)$ & $\mathrm{F}$ & $51-60$ \\
\hline 6 & bla-tem, bla-shv, bla-ctxm, cat 2, cat 3, qnrA, aac $\left(6^{\prime}\right)-I b-c r$, strA-strB, aacCl & $9(39.1)$ & $\mathrm{F}$ & $41-50$ \\
\hline 7 & cat 1, cat 2, qnrB, sul1, sul2, strA-strB, aacCl & $5(21.7)$ & $\mathrm{M}$ & $51-60$ \\
\hline 8 & cat 1, cat 2, qnrA, sul 1, str $A-\operatorname{str} B$ & $5(21.7)$ & M & $41-50$ \\
\hline 9 & bla-ctxm, cat 1, cat $2, q n r A, q n r B$, sul 2 & $6(26)$ & $\mathrm{F}$ & $41-50$ \\
\hline 10 & cat 2, gnrA, aac(6')-Ib-cr, sul1, sul2 & $5(21.7)$ & $\mathrm{F}$ & $41-50$ \\
\hline 11 & bla-tem, bla-ctxm, qnrA, sul2, strA-strB & $5(21.7)$ & M & $31-40$ \\
\hline 12 & bla-shv, cat 1, cat $3, q n r A, a a c\left(6^{\prime}\right)-I b-c r$, sul $1, \operatorname{str} A-\operatorname{str} B$ & $5(21.7)$ & $\mathrm{M}$ & $31-40$ \\
\hline 13 & bla-tem, bla-shv, bla-ctxm, bla-ctxm-2, qnrA, sul1, sul2, strA-str $B$ & $8(34.7)$ & M & $31-40$ \\
\hline 14 & bla-tem, bla-ctxm, bla-ctxm-1, cat 1, qnrA, sul2, strA-strB & $7(30.4)$ & $\mathrm{F}$ & $41-50$ \\
\hline 15 & bla-shv, bla-ctxm, bla-ctxm-1, cat 1, cat 3, qnrA, strA-strB & $7(30.4)$ & $\mathrm{F}$ & $18-30$ \\
\hline 16 & bla-tem, bla-shv, bla-ctxm, bla-ctxm-2, qnrA, aac(6')-Ib-cr, strA-strB & $7(30.4)$ & $\mathrm{F}$ & $18-30$ \\
\hline 17 & bla-shv, bla-ctxm, cat $1, q n r B$, aac $\left(6^{\prime}\right)-I b-c r, \operatorname{str} A-\operatorname{str} B$ & $6(26)$ & $\mathrm{F}$ & $41-50$ \\
\hline 18 & bla-tem, bla-shv, bla-ctxm, gnrA, strA-strB & $5(21.7)$ & $\mathrm{F}$ & $31-40$ \\
\hline 19 & bla-tem, bla-ctxm, bla-ctxm-2, cat 1, qnr $A$, aac $\left(6^{\prime}\right)-I b-c r$, sul 1, str $A-s t r B$ & $8(34.7)$ & $\mathrm{F}$ & $41-50$ \\
\hline 20 & bla-shv, cat 1, qnrA, qnrB, aac(6')-Ib-cr, sul1, strA-strB & $7(30.4)$ & $\mathrm{F}$ & $31-40$ \\
\hline 21 & bla-shv, bla-ctxm, bla-ctxm-2, cat 1, str $A-s t r B$ & $5(21.7)$ & $\mathrm{F}$ & $31-40$ \\
\hline 22 & bla-shv, bla-ctxm, strA-strB & $3(13)$ & $\mathrm{F}$ & $31-40$ \\
\hline 23 & bla-tem, bla-ctxm, cat 1 & $3(13)$ & $\mathrm{F}$ & $51-60$ \\
\hline 24 & bla-ctxm, bla-ctxm-2, cat 1, sul2, str $A$-str $B$ & $5(21.7)$ & $\mathrm{F}$ & $51-60$ \\
\hline 25 & bla-ctxm, bla-ctxm-2, sul2, strA-strB & $4(9.2)$ & $\mathrm{F}$ & $41-50$ \\
\hline 26 & bla-tem. bla-ctxm, cat 1, gnr $A$, gnrB, sul2, strA-strB & $7(30.4)$ & $\mathrm{F}$ & $41-50$ \\
\hline 27 & bla-tem, bla-shv, bla-ctxm, cat 1, qnrB, strA-str $B$ & $6(26)$ & M & $41-50$ \\
\hline 28 & $q n r A, q n r B, \operatorname{str} A-s t r B$ & $3(13)$ & $\mathrm{M}$ & $41-50$ \\
\hline 29 & bla-shv, bla-ctxm, strA-strB & $3(13)$ & M & $51-60$ \\
\hline 30 & bla-shv, bla-ctxm, cat 1 & $3(13)$ & M & $51-60$ \\
\hline
\end{tabular}

No(\%): Numbers and percentages of Citrobacter freundii isolates that were carried to antimicrobials resistance associated genes, F: Female, M: Male

\section{Discussion}

The TEM catalysts was one of the initially stretched out range beta lactamase to be distinguished, first found in 1965. The TEM sort $\beta$ lactamase was named after the E. coli contaminated patient, Temoneira, in Athens, Greece (Aljanaby and Aljanaby, 2018a). What's more, the bla-tem quality (encoding the protein) is normally found on plasmids (Matsumoto et al., 2014). In current study out of 30 isolates, there were 15 isolates with percentage rate $(50 \%)$ were positive for bla-tem gene. This result is in agreement with the study by Praharaj et al. (2016) in India, who showed $50 \%$ of $C$. freundii isolated from urinary tract infections samples were positive to bla-tem gene. A similar study by DelgadoValverde et al. (2016) reported that $65.8 \%$ of $C$. freundii isolates were positive to bla-tem gene. However, other study demonstrated that there was $10.4 \%$ of $C$. freundii isolates were positive to bla-tem gene (Akinduti et al., 2011). Extended spectrum beta lactamase enzymes have been derived from TEM and SHV genes by mutations and have been well described in Enterobacteriaceae family (Liakopoulos et al., 2016).

In the current study, Molecular detection of some antimicrobials resistance genes were detected by PCR using specific primer sequences. In the present study 16 isolates with percentage rate $(53.3 \%)$ were positive for bla-shv gene. The current study result is in agreement with those previously reported (Sharma et al., 2016) showing $57.5 \%$ of $C$. freundii isolates from urinary tract infection samples were positive to bla-shv gene. Another study in Madagascar by Chereau et al. (2015) showed that there was $66.6 \%$ of $C$. freundii isolates from pregnant women urinary tract samples were positive to bla-shv gene. In the current years, another group of plasmid-interceded ESBLs (extended spectrum beta lactamase) called CTX-M which specially hydrolyze cefotaxime, has risen and the bla-ctxm quality is typically found on plasmids. CTX-M catalysts have for the most part been found in strains of Salmonella enterica serovar Typhimurium and E. coli, however have likewise been depicted in different types of Enterobacteriaceae (Brown et al., 2018). Not at all like different ESBLs sorts, CTX-M family incorporates a complex and non-comparable gathering of catalysts. The primary investigation and arrangement of the amino corrosive groupings of the CTX-M variations ordered 
these catalysts into five bunches (CTX-M-1, CTX-M-2, CTX-M-8, CTX-M-9 and CTX-M-25) (Aljanaby and Alhasnawi, 2017). CTX-M $\beta$-lactamases rose not by changes from prior plasmid intervened catalysts but rather by preparation of chromosomal bla qualities from microscopic organisms are firmly identified with Escherichia coli and discovered around the world, activation of bla-ctxm qualities happened by inclusion successions or by lesser degree bacteriophages. The inclusion succession assumes a part in the over-articulation of bla-ctxm qualities (Tamang et al., 2013). The bla qualities were coordinated into portable hereditary structures and exchanged probably by conjugation into clinical microscopic organisms (Hardiman et al., 2016). These prepared bla-ctxm qualities increment cefotaxime imperviousness to a significantly more prominent degree than imperviousness to ceftazidime (Aljanaby, 2018). The consequences of present study additionally showed that 21 isolates $(70 \%)$ were positive for bla-ctxm gene, 3 isolates (10\%) were positive for bla-ctxm-1 gene, 6 isolates (20\%) were positive for bla-ctxm-2 gene, while, there was positive isolate carrying pse 1 , bla-ctxm-8, bla-ctxm-9 and bla-ctxm-25 genes. This is supportive to previously published study (Castanheira et al., 2017) showing that there was $35.5 \%$ of $C$. frundii isolates were from samples revealed that ESBL (extended spectrum beta lactamase) producing isolates have bla-ctxm genes, these result is not in agreement with this study result. Chloramphenicol is one of the first broad-spectrum antibiotics used to treat grampositive and gram-negative bacterial infections; the major resistance of mechanism to chloramphenicol is enzymatic inactivation by the plasmid transposon-mediated chloramphenicol acetyl transferees cat 1 gene and cat2 gene (Huang et al., 2017). Quinolones are expansive range antibacterial specialists, generally utilized for treatment of contaminations therefore, upgraded level of quinolone resistance has happened as of late for instance fluoroquinolones, for example, ciprofloxacin, beforehand appeared to have incredible action against clinical disengages of $C$. freundii, have turned out to be less successful because of their broad utilize (Aldred et al., 2014). Quinolones are broad-spectrum antibacterial agents, commonly used for treatment of infections as a result, enhanced level of quinolone resistance has occurred in recent years (Aljanaby et al., 2018). Mechanisms of Quinolone resistance is mediated by the mutation of chromosomal genes encoding DNA gyrase and/or topoisomerase IV or by the mutation of genes regulating the expression of efflux pumps (Correia et al., 2017). qnr gene found on plasmid, quinolone resistance may also be related to plasmid-mediated quinolone resistance genes, (qnrA, qnrB and $\left.a a c\left(6^{\prime}\right) I b-c r\right)$ (Aljanaby and Medhat, 2017). The $q n r A$ and $q n r B$ genes are coding for proteins belonging to the penta peptide repeat family interacting with DNA gyrase and topoisomerase IV enzymes to prevent quinolone inhibition (Aljanaby and Aljanaby, 2018b). Another plasmid mediated quinolone resistance gene is aac (6)-Ib-cr, which encodes aminoglycoside acetyltransferase enzyme. This enzyme which can diminish a fluoroquinolone activity by adding an acetyl group to this antibiotic (Ramirez and Tolmasky, 2017) Sulfa drugs are an important class of synthetic bacteriostatic antibiotics still used today for the treatment of bacterial infections and those caused by other microorganisms, sulfa drugs achieve this bacteriostatic action by inhibiting the synthesis of folic acid in bacteria (Shama, 2015). They are also known as sulfa drugs and were the main source of therapy against bacterial infections before the introduction of penicillin in 1941. Although sulfonamides have for the most part been replaced by other agents, they still maintain considerable action in certain types of infection, for example in the urinary tract, eye and ear infections (Kapoor et al., 2017). Aminoglycosides are highly potent, broad-spectrum antibiotics with many desirable properties for the treatment of life-threatening infections. Their history begins in 1944 with streptomycin and was thereafter marked by the successive introduction of a series of milestone compounds (kanamycin, gentamicin and tobramycin) which definitively established the usefulness of this class of antibiotics for the treatment of gram-negative bacillary infections (Krause et al., 2016). Streptomycin is an aminoglycoside antibiotic produced by the soil actinomyces Streptomyces griseus. It acts by binding to the $30 \mathrm{~S}$ ribosomal subunit of susceptible organisms and disrupting the initiation and elongation steps in protein synthesis. It is bactericidal due to effects that are not fully understood (Aljanaby, 2013). The tetracycline which were discovered in the 1940s, are a family of antibiotics that inhibit protein synthesis by preventing the attachment of aminoacyl-tRNA to the ribosomal acceptor (A) site. Tetracycline are broadspectrum agents, exhibiting activity against a wide range of gram-positive and gram-negative bacteria (Krause et al., 2016). In USA 2008, the study by Srinivasan et al. (2008) who showed that the $\operatorname{str} A-\operatorname{str} B$ gene was most prevalence gene in $C$. freundii isolates with $4.6 \%$ rate of, these result is not in agreement with present study. The study by Igbinosa et al. (2018) in Nigeria, showed that the prevalence of multidrug resistance isolates where it contains further antibiotic resistance genes, including those for aminoglycosides (strA and strB), beta-lactams (bla-tem), chloramphenicol (cat2), sulfonamide (sul2), tetracycline 
(tetA) and trimethoprim (dfrA14). In conclusion: Citrobacter freundii harbor large numbers of different antimicrobial resistance-associated genes that enable this pathogen to be more virulent and make it highly resistant against most antimicrobials and became more dangerous bacteria cause urinary tract infection.

\section{Acknowledgement}

The authors are very thankful to all staff of laboratory of Al Najaf central hospital in Al-Najaf City for provided all urine samples.

\section{Authors' Contributions}

Ahmed Abduljabbar Jaloob Aljanaby: Designed the study, performed the statistical analyses and wrote the manuscript.

Thualfakar Hayder: Collected, cultured and identified of all bacterial isolates, DNA extracted, PCR technique and wrote the manuscript.

\section{Conflict of Interest}

The authors declare that they have no conflict of interest.

\section{References}

Adesiji, Y.O., V.K. Deekshit and I. Karunasagar, 2014. Antimicrobial-resistant genes associated with Salmonella spp. isolated from human, poultry and seafood sources. Food. Sci. Nutr., 2: 436-442.

DOI: $10.1002 /$ fsn3.119

Akinduti, P.A., A. Oluwadun, B. Iwalokun and E. Oluwaseun, 2011. Clonal Dissemination of blaTEM S-lactamase Strains among Enteric Isolates in Abeokuta, Nigeria. Res. J. Microbiol., 6: 919-925. DOI: $10.3923 / \mathrm{jm} .2011 .919 .925$

Aldred, K.J., R.J. Kerns and N. Osheroff, 2014. Mechanism of quinolone action and resistance American chemical society. Biochemistry, 53: 1565-1574. DOI: $10.1021 /$ bi5000564

Aljanaby, A.A. and F.A. Gafil, 2013. Effect of different antibiotics on aerobic pathogenic bacteria and urinary tract infection in Al-Manathera City, Iraq: A comparative study. Res. Chem. Intermed., 39: 3679-3687. DOI 10.1007/s11164-012-0871-8

Aljanaby, A.A.J. and I.A.J. Aljanaby, 2017. Profile of antimicrobial resistance of aerobic pathogenic bacteria isolated from different clinical infections in Al-Kufa Central Hospital-Iraq during period from 2015 to 2017. Res. J. Pharm. Tech., 10: 3264-3270.
Aljanaby, A.A.J. and H.M.R.J. Alhasnawi, 2017. Phenotypic and molecular characterization of multidrug resistant Klebsiella pneumoniae Isolated from different clinical sources in Al-Najaf Province-Iraq. Pak. J. Biol. Sci., 20: 217-232. DOI: $10.3923 /$ pjbs.2017.217.232

Aljanaby, A.A.J. and A.R. Medhat, 2017. Prevalence of some antimicrobials resistance associated-genes in salmonella typhi isolated from patients infected with typhoid fever. J. Biol. Sci., 17: 171-184.

DOI: $10.3923 /$ jbs.2017.171.184

Aljanaby, A.A.J. and I.A.J. Aljanaby, 2018a. Prevalence of aerobic pathogenic bacteria isolated from patients with burn infection and their antimicrobial susceptibility patterns in Al-Najaf City, Iraq-a three-year crosssectional study. F1000 Res., 7: 1157-1157. DOI: 10.12688/f1000research.15088.1

Aljanaby, A.A.J., 2018. Antibiotics susceptibility pattern and virulence-associated genes in clinical and environment strains of pseudomonas aeruginosa in Iraq. Asian J. Sci. Res., 11: 401-408. DOI: 10.3923/ajsr.2018.401.408

Aljanaby, A.A.J., N.S.S. Tuwaij and H.J.B. Al-khilkhali, 2018. Antimicrobial susceptibility patterns of Klebsiella pneumoniae isolated from older smokers and non-smokers of inpatients in intensive care unit infected with chronic pneumonia in AL-Najaf hospital, Iraq. J. Pharm. Sci. Res., 10: 1093-1097

Aljanaby, A.A.J. and I.A.J. Aljanaby, 2018b. Antimicrobial sensitivity pattern of pathogenic bacteria isolated from older women with asymptomatic bacteriuria. Biomed. Res., 29: 2597-2601. DOI: 10.4066/biomedicalresearch.29-18-601

Bae, J.Y., K.K. Chang, C.J. Su., L. Eunyoung and P.B. Wan, et al., 2018. Sudden deaths of neonates receiving intravenous infusion of lipid emulsion contaminated with citrobacter freundii. J. Korean Med. Sci., 33: e97-e97. DOI: 10.3346/jkms.2018.33.e97.

Bacci, C., E. Boni, I. Alpigiani, E. Lanzoni, S. Bonardi and F. Brindani , 2012. Phenotypic and genotypic features of antibiotic resistance in Salmonella enterica isolated from chicken meat and chicken and quail carcasses. Int. J. Food. Microbiol., 160: 16-23. DOI: 10.1016/j.ijfoodmicro.2012.09.014.

Brown, A.C., C.C. Jessica., K. Louise, W. Francois and P Jason et al., 2018. CTX-M-65 extended-spectrum $\beta$-lactamase-producing Salmonella enterica serotype infantis, United States. Emerg. Infect. Dise., 24: 2284-2291. DOI: 10.3201/eid2412.180500

Castanheira, M., R.E. Mendes, T.B. Doyle, A.P. Davis and H.S. Sader, 2017. Characterization of enterobacter and Citrobacter spp isolates from united states hospitals by whole Genome sequencing analysis and activity of ceftazidime-avibactam and comparator agents. Open Forum Infect Dis., 15: 2-2. DOI: $10.1093 /$ ofid/ofx 163.178 
Chu, C., C.H. Chiu, W.Y. Wu, C.H. Chu and J.T. Ou et al., 2001. Large drug resistance virulence plasmids of clinical isolates of Salmonella enterica serovar Choleraesuis. Antimicrobial Agents Chemotherapy, 45: 2299-2303.

DOI: 10.1128/AAC.45.8.2299-2303.2001

Chereau, F., P. Herindrainy, B. Garin, B.T. Huynh and F. Randrianirina et al., 2015. Colonization of extendedspectrum-lactamase-and NDM-1producing Enterobacteriaceae among pregnant women in the community in a low-income country: a potential reservoir for transmission of multiresistant Enterobacteriaceae to neonates. Antimicrob. Agents Chemother., 59: 3652-3655. DOI: $10.1128 / A A C .00029-15$

Correia, S., P. Poeta, H. Michel, J.L. Capelo and G. Igrejas, 2017. Mechanisms of quinolone action and resistance: where do we stand? J. Med. Micro., 66: 551-559. DOI: 10.1099/jmm.0.000475

Delgado-Valverde, M., J. Sojo-Dorado, A. Pascual and R. Baño, 2016. Clinical management of infections caused by multidrug-resistant Enterobacteriaceae. Therapeutic Adv. Infect. Dis., 1: 49-69. DOI: $10.1177 / 2049936113476284$

De Vito, D., R. Monno, F. Nuccio, M. Legretto, M.Oliva , M.F.Coscia, A.M. Dionisi, C.Calia, C. Capolongo and C. Pazzani, 2015. Diffusion and persistence of multidrug resistant Salmonella Typhimurium strains phage type DT120 in southern Italy. Biomed. Res. Int., 2015: 265042. DOI: 10.1155/2015/265042

Du, J., Li, P., Liu, H., Lü, D., Liang, H. and Dou, Y., 2014. Phenotypic and molecular characterization of multidrug resistant Klebsiella pneumoniae isolated from a university teaching hospital, China. PloS one, 9: e95181. DOI: 10.1371/journal.pone.0095181.

Hardiman, C.A., R.A. Weingarten, S. Conlan, P. Khil and J.P. Dekker et al., 2016. Horizontal transfer of carbapenemase encoding plasmids and comparison with hospital epidemiology data. Antimicrobial. Agents Chemother., 60: 4910-4919.

DOI: 10.1128/AAC.00014-16

Hossain, S., S. Wimalasena and H. Gang-Joon, 2017. Virulence factors and antimicrobial resistance pattern of Citrobacter freundii isolated from healthy pet turtles and their environment. Asian J. Anim. Vet. Adv., 12: 10-16. DOI: 10.3923/ajava.2017.10.16

Huang, L., H. Yuan, M.F. Liu, X.X. Zhao and M.S. Wang et al., 2017. Type B chloramphenicol acetyltransferases are responsible for chloramphenicol resistance in riemerella anatipestifer. China Front. Microbiol., 8: 297. DOI: $10.3389 /$ fmicb.2017.00297
Hujer, K.M., A.M. Hujer, E.A. Hulten, S. Bajaksouzian, J.M. Adams and C.J. Donskey et al.,2006. Analysis of antibiotic resistance genes in multidrug-resistant Acinetobacter sp. Isolates from military and civilian patients treated at the Walter Reed Army Medical Center. Antimicrob Agents Chemother., 50: 4114-4123. DOI: 10.1128/AAC.00778-06

Igbinosa, E.O., J. Rathje, D. Habermann, E. Brinks and C. Franz, 2018. Draft genome sequence of multidrugresistant strain Citrobacter portucalensis MBTC-1222, isolated from uziza (Piper guineense) leaves in Nigeria. Genome Announc., 6: e00123-18-e00123-18. DOI: 10.1128/genomeA.00123-18

Iraz, M., A. Özad Düzgün, C. Sandallı, M.Z. Doymaz and Akkoyunlu et al., 2015. Distribution of $\beta$ lactamase genes among carbapenem-resistant Klebsiella pneumoniae strains isolated from patients in Turkey. Ann. Laboratory Med., 35: 595-601. DOI: 10.3343/alm.2015.35.6.595

Kapoor, G., S. Saigal and A. Elongavan, 2017. Action and resistance mechanisms of antibiotics: A guide for clinicians. J Anaesthesiol. Clin. Pharmacol., 33: 300-305. DOI: 10.4103/joacp.JOACP 349_15

Krause, K.M., A.W. Serio, T.R. Kane and L. Connolly, 2016. Aminoglycosides: An overview. Cold Spring Harb Perspect Med., 1: a027029-a027029.

DOI: $10.1101 /$ cshperspect.a027029

Levings, R.S., D. Lightfoot, S.R. Partridge, R.M. Hall and S.P. Djordjevic, 2005. The genomic island SGI1, containing the multiple antibiotic resistance region of Salmonella enterica serovar Typhimurium DT104 or variants of it, is widely distributed in other $\mathrm{S}$. enterica serovars. J. Bacteriology, 187: 4401-4409.

DOI: $10.1128 /$ JB.187.13.4401-4409.2005

Liakopoulos, A., D. Mevius and D. Ceccarelli, 2016. A review of SHV extended-spectrum $\beta$-lactamases: Neglected yet ubiquitous. Front Microbiol., 7: 1374-1374. DOI: 10.3389/fmicb.2016.01374

Liu, L., R. Lan, L. Liu., Y. Wang and J. Xu et al., 2017. Antimicrobial resistance and cytotoxicity of Citrobacter spp. in Maanshan Anhui Province, China. Front Microbiol., 8: 1357. DOI: $10.3389 /$ fmicb.2017.01357

Liu, L.H., N.Y. Wang, A.Y. Wu, C.C. Lin and C.P. Liu et al., 2018. Citrobacter freundii bacteremia: Risk factors of mortality and prevalence of resistance genes. J. Microbiol. Immunol. Infect., 51: 565-572. DOI: $10.1016 /$ j.jmii.2016.08.016

Mac Faddin, J.F., 2000. Biochemical Tests for Identification of Medical Bacteria. 2nd Edn., Williams and Wilkins, Philadelphia, ISBN-10: 0683053159, pp: 912. 
Matsumoto, Y., H. Izumiya, T. Sekizuka, M. Kuroda and M. Ohnishi, 2014. Characterization of blaTEM-52carrying plasmids of extended-spectrum- $\beta$ lactamase-producing Salmonella enterica isolates from chicken meat with a common supplier in Japan. Antimicrob. Agents Chemother., 58: 7545-7. DOI: 10.1128/AAC.02731-14

Newire, E.A., S.F. Ahmed, B. House, E. Valiente and G. Pimentel, 2013. Detection of new SHV-12, SHV5 and SHV-2a variants of extended spectrum betalactamase in Klebsiella pneumoniae in Egypt. Annals Clinical Microbiology Antimicrobials, 1: 16. DOI: $10.1186 / 1476-0711-12-16$

Plakkal, N., A.S. Soraisham and H. Amin, 2013. Citrobacter freundii brain abscess in a preterm infant: A case report and literature review. Pediatr Neonatol., 54: 137-40. DOI: 10.1016/j.pedneo.2012.10.004

Praharaj, A.K., A. Khajuria, M. Kumar and N. Grover, 2016. Phenotypic detection and molecular characterization of beta-lactamase genes among Citrobacter species in a tertiary care hospital. Avicenna J. Med., 6: 17-27.

DOI: $10.4103 / 2231-0770.173578$

Ramirez, M.S. and M.E. Tolmasky, 2017. Amikacin: Uses, resistance and prospects for inhibition. Molecules, 19: E2267-E2267. DOI: 10.3390/molecules22122267

Robicsek, A., J. Strahilevitz, G.A. Jacoby, M. Macielag, D. Abbanat, 2006. Fluoroquinolone-modifying enzyme: A new adaptation of a common aminoglycoside acetyltransferase. Nat Med., 12: 83-88. DOI: $10.1038 / \mathrm{nm} 1347$

Shama, G., 2015. The role of the media in influencing public attitudes to penicillin during World War II. Dynamis, 35: 131-152.

Sharma, A., B. Shrestha, P. Parajuli and R. Suwal, 2016. A comparative study of microorganisms adhered to different surfaces of complete dentures. EC Dental Sci.
Shams, E., F. Firoozeh, R.Moniri and M.Zibaei, 2015. Prevalence of Plasmid Mediated Quinolone Resistance Genes among Extended Spectrum $\beta$-Lactamase Producing Klebsiella pneumoniae Human Isolates in Iran. J. Pathog., 434391. DOI: 10.1155/2015/434391

Srinivasan, V., H.M. Nam, A.A. Sawant, S.I. Headrick and S.P. Oliver et al., 2008. Distribution of tetracycline and streptomycin resistance genes and class 1 integrons in enterobacteriaceae isolated from dairy and nondairy farm soils. Microb. Ecol., 55: 184-93. DOI: 10.1007/s00248-007-9266-6

Tamang, M.D., H.M. Nam, S.R. Kim, M.H. Chae and G.C. Jang et al., 2013. Prevalence and molecular characterization of CTX-M $\beta$-lactamase-producing escherichia coli isolated from healthy swine and cattle. Foodborne Pathog Dis., 10: 13-20. DOI: $10.1089 /$ fpd.2012.1245

Tan, C.K., K.B. Ulett, M. Steele, W.H. Benjamin and G.C. Ulett, 2012. Prognostic value of semi-quantitative bacteruria counts in the diagnosis of group B streptococcus urinary tract infection: A 4-year retrospective study in adult patients. BMC Infect. Dis., 26: 112-273. DOI: 10.1186/1471-2334-12-273

Yang, J.L., M.S. Wang, A.C. Cheng, K.C. Pan and S.X. Deng et al., 2008. A simple and rapid method for extracting bacterial DNA from intestinal microflora for ERIC-PCR detection. World J. Gastroenterol., 14: 2872-2876. DOI: $10.3748 /$ wjg. 14.2872 